\title{
Effects of Quercetin on the Efficacy of Various Chemotherapeutic Drugs in Cervical Cancer Cells
}

\author{
Wenbin $\mathrm{Xu}^{*}$ \\ Shangdan Xie* \\ Xin Chen \\ Shuya Pan \\ Hongfei Qian \\ Xueqiong Zhu (D) \\ Center of Uterine Cancer Diagnosis \& \\ Therapy Research of Zhejiang Province, \\ Department of Obstetrics and \\ Gynecology, The Second Affiliated \\ Hospital of Wenzhou Medical University, \\ Wenzhou, Zhejiang, 325027, People's \\ Republic of China \\ *These authors contributed equally to \\ this work
}

This article was published in the following Dove Press journal:

Drug Design, Development and Therapy

Purpose: This study aimed to investigate the effects of quercetin on the efficacy of various chemotherapeutic drugs in cervical cancer cells.

Methods: All drug experiments were performed in $\mathrm{HeLa}$ and $\mathrm{SiHa}$ cells. The cell viability was detected by Cell Counting Kit-8 assay, and cell proliferation was estimated by bromodeoxyuridine assay. CompuSyn software was utilized to calculate the combination index (CI) and evaluate the synergistic or antagonistic effect of quercetin with cisplatin, paclitaxel, 5-fluorouracil and doxorubicin on cell viability. Cell migration and invasion abilities were detected by transwell assays, and cell apoptosis was measured by flow cytometry. The expression levels of matrix metallopeptidase 2 (MMP2), ezrin, P-glycoprotein (P-Gp) and methyltransferase-like 3 (METTL3) protein treated with various drugs were analyzed by Western blotting.

Results: Quercetin inhibited the viability of HeLa and SiHa cells in a dose- and timedependent manner. The CI values of quercetin with cisplatin, paclitaxel, 5-fluorouracil and doxorubicin were $<1,>1,>1$ and $>1$, respectively. The effect of combination of quercetin and cisplatin on cell proliferation was stronger than their individual effects. Co-treatment group could inhibit more cell migration and invasion in contrast to single-drug group. Besides, quercetin combined with cisplatin group induced more cell apoptosis in contrast to singledrug group. The results of Western blotting showed that the expression levels of MMP2, ezrin, P-Gp and METTL3 in co-treatment group were lower than in cisplatin group, respectively.

Conclusion: Quercetin and cisplatin had synergistic inhibitory effect on cervical cancer cells. Quercetin might enhance the antitumor effect of cisplatin via inhibiting proliferation, migration and invasion and elevating apoptosis through weakening MMP2, ezrin, METTL3 and P-Gp expression of cancer cells.

Keywords: quercetin, cisplatin, cervical cancer, chemosensitivity

\section{Introduction}

Cervical cancer, one of the most common malignances in women, is estimated to cause 13,800 new cases and 4290 deaths in the United States in 2020. ${ }^{1}$ Papanicolaou test and HPV test are the two chief diagnostic tests for cervical cancer screening. ${ }^{2}$ Although the spread of early screening and HPV vaccination reduce the incidence of cervical cancer, ${ }^{3}$ the mechanism of recurrence and drug resistance in patients with advanced cervical cancer is not well understood. Concurrent chemoradiotherapy is the standard treatment for locally advanced disease (FIGO IIB-IVA) and improves outcomes of
Correspondence: Xueqiong Zhu

Therapy Research of Zhejiang Province,

Department of Obstetrics and Gynecology,

The Second Affiliated Hospital of Wenzhou

Medical University, No. 109 Xueyuan Xi

Road, Wenzhou, Zhejiang, 325027, People's

Republic of China

Tel +8657788002796 (office)

Fax +8657788002796

Email zjwzzxq@163.com 
cervical cancer patients markedly. ${ }^{4}$ Cisplatin-based neoadjuvant chemotherapy and concurrent chemoradiotherapy are common therapeutic regimes for women with advanced cervical cancer. ${ }^{5}$ In addition to locally advanced disease, the effect of neoadjuvant chemotherapy on early stage (FIGO IB-IIA) disease prior to surgery or radiation has been also studied extensively. ${ }^{6}$ Paclitaxel, 5-fluorouracil and doxorubicin are common second-line drugs in the treatment of cervical cancer. However, chemoresistance of cancer cells, both of intrinsic and acquired resistance, may compromise chemotherapeutic drugs' efficacy and hinder wider application. ${ }^{7-10}$ Polychemotherapy schemes have been found to be better than single agent regimens. ${ }^{11}$

Quercetin (3,3',4',5,7-pentahydroxyflavone), a polyphe nolic flavonoid, exerts anticancer activity in numerous cancers. ${ }^{12,13}$ Increasing numbers of studies demonstrate that quercetin induces apoptosis of cervical cancer cells through various signal pathways. ${ }^{14-16}$ Recently, the combination of quercetin and anticancer chemicals has been extensively studied in multiple cancer cells. Quercetin enhances the sensitivity of prostate cancer cells to paclitaxel ${ }^{17}$ and has a synergistic effect with cisplatin on oral squamous cell carcinoma. ${ }^{18}$ However, so far, no published research has demonstrated the effect of quercetin on efficacy of chemotherapeutic drugs in cervical cancer cells.

The present study aimed to research the effects of quercetin on the efficacy of various chemotherapeutic drugs in cervical cancer HeLa and SiHa cells. Besides, the influence of quercetin and cisplatin on the expression levels of matrix metallopeptidase 2 (MMP2), ezrin, methyltransferase-like 3 (METTL3) and P-glycoprotein (P-Gp) in cervical cancer cells was explored. This study may suggest a novel thread of therapeutic strategy to treat cervical cancer based on a series of experimental results.

\section{Materials and Methods}

\section{Cell Lines and Cell Culture}

Human cervical cancer cells, HeLa and $\mathrm{SiHa}$, used in this study were purchased from Shanghai Cell Biology Medical Research Institute, Chinese Academy of Sciences. The cell lines were cultured in Dulbecco's modified Eagle's Medium (DMEM, Gibco, USA) containing $10 \%$ fetal bovine serum (Gibco, USA). All the cells were incubated in a humidified atmosphere containing $5 \% \mathrm{CO}_{2}$ at $37^{\circ} \mathrm{C}$ for growth.

\section{Reagent and Antibodies}

Quercetin (Sigma, USA) was prepared into a $200 \mathrm{mM}$ stock using dimethyl sulfoxide (DMSO) and stored at $-20^{\circ} \mathrm{C}$. The working concentration of $200 \mu \mathrm{M}$ quercetin was made in a complete medium, and a range of concentrations of quercetin $(10,20,50,100,150$ and $200 \mu \mathrm{M})$ was utilized in cell viability assay. Cisplatin (Sigma, USA) and paclitaxel (MedChemExpress, USA) were stored at $-20^{\circ} \mathrm{C}$, while 5-fluorouracil (Solarbio, China) and doxorubicin (Solarbio, China) were stored at $4^{\circ} \mathrm{C}$. Primary antibodies for MMP2 (monoclonal rabbit anti-human antibody; 1:1000), ezrin (polyclonal rabbit anti-human; 1:1000) and GAPDH (monoclonal rabbit anti-human antibody; 1:1000) were purchased from Cell Signaling Technology, and P-Gp (monoclonal rabbit anti-human antibody; 1:1000) and METTL3 (monoclonal rabbit anti-human antibody; 1:1000) were purchased from Abcam (1:1000, USA); and the second antibody, peroxidase-conjugated goat anti-rabbit antibody, was obtained from Biosharp (1:5000, USA). Diaminobenzidine (DAB) Substrate Kit was purchased from Zhongshan Goldenbridge (China).

\section{Cell Viability Assay}

A total of $5000 \mathrm{HeLa}$ or $\mathrm{SiHa}$ cells were plated in 96-well plates and incubated overnight to adhere. After attachment, the original medium was replaced by a complete medium containing the following concentrations of quercetin $(0,10,20,50$, 100,150 and $200 \mu \mathrm{M}$ ) for $24 \mathrm{~h}$ or $48 \mathrm{~h}$. As for cisplatin treatment, cells were incubated with a range of concentrations of cisplatin $(0,10,20,50$ and $100 \mu \mathrm{M})$ for $24 \mathrm{~h}$ or $48 \mathrm{~h}$ after adherence. Besides, a series of concentrations of paclitaxel $(0$, $0.01,0.02,0.05$ and $0.1 \mu \mathrm{M}), 5$-fluorouracil $(0,0.2,0.5,1,5$, 10 and $20 \mu \mathrm{M}$ for HeLa, 0, 10, 20, 50, 100, 150 and $200 \mu \mathrm{M}$ for $\mathrm{SiHa})$ and doxorubicin $(0,0.05,0.1,0.2,0.5,1$ and $5 \mu \mathrm{M})$ were applied to incubate cervical cancer cells, respectively. After $24 \mathrm{~h}$ or $48 \mathrm{~h}$ of incubation, Cell Counting Kit-8 (CCK-8, Sigma, USA) was utilized to detect cell viability, and the number of viable cells was assessed by measurement of absorbance at $450 \mathrm{~nm}$ using a Microplate Reader (Bio Tek Instruments, Winooski, VT, USA) after $2 \mathrm{~h}$ incubation. The percent of cell viability relative to the control was calculated using the following equation: $\%$ CellViability $=\frac{\text { Absorbance individual testgroup }- \text { Absorbance blank group }}{\text { Absorbance control group }- \text { Absorbance blank group }}$. Cell viability rate was calculated in GraphPad PRISM version 6.01 statistical program. Then $\mathrm{IC}_{30}$ of cisplatin, paclitaxel, 5-fluorouracil and doxorubicin on $\mathrm{HeLa}$ and $\mathrm{SiHa}$ was chosen 
to be combined with three concentrations of quercetin to be used in cell viability assay.

\section{Drug Combination Therapy Effect Valuation}

Using the Chou and Talalay method, ${ }^{19}$ the drug-drug interaction between quercetin and cisplatin, or between quercetin and other drugs such as paclitaxel, 5-fluorouracil and doxorubicin, was investigated, and the results of combination index (CI) values were calculated using CompuSyn software. The interaction between the two drugs was considered synergism when the CI value existed between 0 and 1 and the $\mathrm{CI}$ value was negatively related to the extent of synergism: $<0.1$, very strong synergism; $0.1-$ 0.3 , strong synergism; $0.3-0.7$, synergism; $0.7-0.85$, moderate synergism; 0.85-0.90, slight synergism; 0.9-1.1, nearly additive; $>1.1$, antagonism. Hence, the CI values of various combinations contributed to the final cotreatment concentrations of quercetin and cisplatin. Thus, there were four groups in the following experiments: control group, quercetin group, cisplatin group and cotreatment group.

\section{Bromodeoxyuridine (BrdU) Incorporation Assay}

A total of $1.5 \times 10^{5} /$ well HeLa or $\mathrm{SiHa}$ cells were seeded into 6-well plates with a glass slide/well and were cultivated in a $37^{\circ} \mathrm{C}$ incubator with $5 \% \mathrm{CO}_{2}$ overnight for adherence. Then cells were treated with corresponding treatments for $24 \mathrm{~h}$ or $48 \mathrm{~h}$ according to grouping. Then BrdU ( $1 \mathrm{mg} / \mathrm{mL})$ was added into each well for incubating $8 \mathrm{~h}$. The medium was removed and the cells were rinsed three times with Phosphate Buffered Saline (PBS). After that, 4\% paraformaldehyde was added to fix the cells for $20 \mathrm{~min}$, and PBS was utilized to rinse the cells three times. Hydrochloric acid (HCL) $2 \mathrm{~mol} / \mathrm{L}$ was supplemented to cultivate the cells for $5 \mathrm{~min}$ at $37^{\circ} \mathrm{C}$, and afterwards PBS was used to rinse them thrice. The cells were incubated with $0.2 \%$ Triton $\times 100$ for $20 \mathrm{~min}$, and then blocked with $3 \%$ bovine serum albumin for $30 \mathrm{~min}$ at room temperature. Then $100 \mu \mathrm{L} /$ glass anti-BrdU antibody (mouse mAb) was added, and the cells were stored at $4^{\circ} \mathrm{C}$ overnight. Then the cells were placed in a $37^{\circ} \mathrm{C}$ incubator for $30 \mathrm{~min}$ to resuscitate. PBS was used to rinse the glass, and dilute goat anti-mouse antibody was added for $1 \mathrm{~h}$ at room temperature. At last, the cells were rinsed with PBS thrice, dyed by $\mathrm{DAB}$ for $60 \mathrm{~s}$ and then hematoxylin for $10 \mathrm{~s}$ and were observed under a microscope with a $200 \times$ magnification. The experiment was repeated three times.

\section{Transwell Invasion and Migration Assay}

Cell invasion and migration assays were performed using polycarbonate filters (8.0 $\mu \mathrm{m}$ pore size; Costar, USA). After drug treatment, the cells $\left(2 \times 10^{4}\right.$ /well for migration, $5 \times 10^{4} /$ well for invasion) were resuspended with $200 \mu \mathrm{L}$ serum-free medium and cultivated in the upper transwell chambers for $24 \mathrm{~h}$ pre-coated with or without matrigel basement membrane matrix (BD, Biosciences, USA), while to the lower chambers was added $600 \mu \mathrm{L}$ complete medium. After culture at $37^{\circ} \mathrm{C}$ for $24 \mathrm{~h}$, the invaded or migrated cells in the lower chamber were fixed with $4 \%$ paraformaldehyde for $30 \mathrm{~min}$, stained with $0.25 \%$ crystal violet (Beyotime, China) for $10 \mathrm{~min}$ at room temperature and observed via a microscope (Nikon, Japan).

\section{Flow Cytometry Analysis}

Cells were cultured at $2 \times 10^{5}$ cells/well into 6-well plates. After 50-60\% confluence, the cells were treated differently according to the above groups. After $24 \mathrm{~h}$ or $48 \mathrm{~h}$, they were harvested, rinsed with PBS and resuspended with $1 \times$ binding buffer at a concentration of 1 $\times 10^{6}$ cells $/ \mathrm{mL}$. Next, $5 \mu \mathrm{L}$ AnnexinV-FITC and $5 \mu \mathrm{L}$ propidium iodide (PI) solution were sequentially added and the cells left for $15 \mathrm{~min}$ at room temperature in the dark. The apoptotic cells were detected using CytoFLEX flow cytometry (Beckman Coulter, Fullerton, USA). The percentage of cells with FITC +/PI- and FITC+/PI+ were determined as the early apoptosis and late apoptosis, respectively. The experiment was repeated three times.

\section{Western Blot Analysis}

Cells were seeded at $5 \times 10^{5}$ cells/dish into $60-\mathrm{mm}$ dishes. After drug treatment, radio immunoprecipitation assay (RIPA) lysis buffer (60 mM Tris-HCl, $\mathrm{pH}$ $6.8,5 \%$ glycerol, $2 \%$ SDS) on ice was used to extract total proteins in the cells, and Bicinchoninic Acid (BCA) Protein Assay kit (Thermo, USA) was utilized to determine the concentrations of proteins. Then $40 \mu \mathrm{g}$ total proteins from each sample was separated in $10 \%$ SDS-PAGE and transferred onto polyvinylidene difluoride (PVDF) membranes (Millipore, USA). The membranes were blocked in 5\% non-fat dried milk prepared with tris buffered saline Tween (TBST) for $1.5 \mathrm{~h}$, rinsed by TBST three times and were incubated 

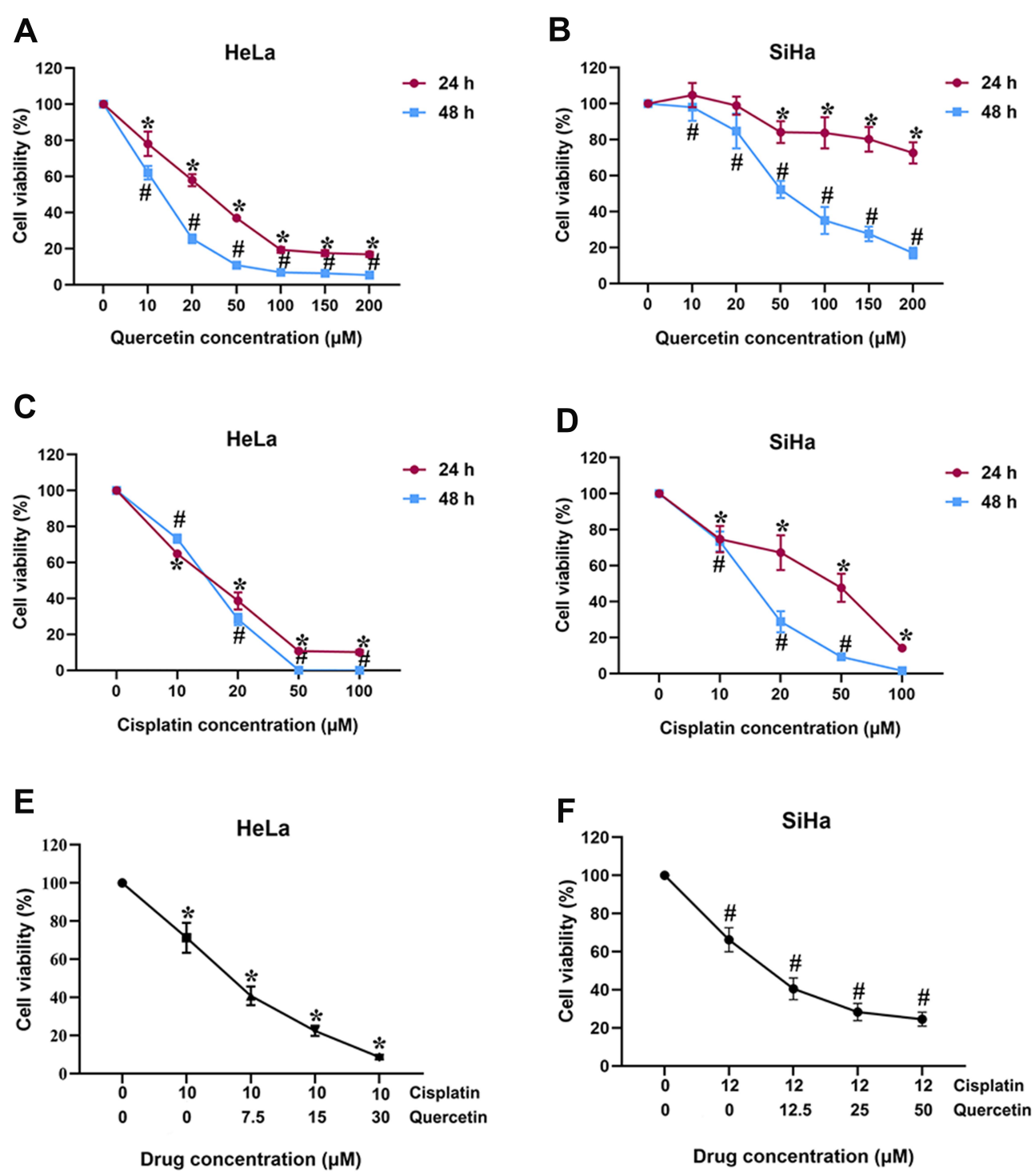

Figure I The effects of quercetin and cisplatin on the viability of cervical cancer cells. (A and B) HeLa and SiHa were exposed to quercetin with various concentrations ( 0 , 10, 20, 50, 100, 150 and $200 \mu \mathrm{M}$ ) for $24 \mathrm{~h}$ and $48 \mathrm{~h}$, respectively; (C and D) HeLa and SiHa were exposed to cisplatin with various concentrations (0, I0, 20 , 50 , I00 $\mu \mathrm{M})$ for $24 \mathrm{~h}$ and $48 \mathrm{~h}$, respectively; (E) HeLa was exposed to combination of various concentrations of quercetin $(0,7.5$ and $15 \mu \mathrm{M})$ and $10 \mu \mathrm{M}$ cisplatin for $24 \mathrm{~h} ;(\mathbf{F})$ SiHa was exposed to combination of various concentrations of quercetin $(0,12.5$ and $25 \mu \mathrm{M}$ ) and $12 \mu \mathrm{M}$ cisplatin for $48 \mathrm{~h}$. $* P<0.05$ vs control group (treatment for $24 \mathrm{~h}$ ). \# $P<0.05$ vs control group (treatment for $48 \mathrm{~h}$ ).

with primary antibodies at $4^{\circ} \mathrm{C}$ overnight. After being rinsed with TBST three times, the membranes were incubated in horseradish peroxidase-conjugated secondary antibodies at room temperature for $1.5 \mathrm{~h}$. The membranes were rinsed with TBST three times, and Immobilon Western Chemiluminescent HRP Substrate (Millipore, USA) was used to develop membranes with chemiluminescence, which was detected by Bio-Rad ChemiDocTM XRS system (Bio-Rad, USA). The intensity of the target protein blots was quantified by Image J software version 1.8.0 (National Institutes of Health, USA).

\section{Statistical Analysis}

Data were statistically analyzed using SPSS 22.0 software (IBM Corporation, USA). All values were expressed as mean \pm standard deviation (SD). Two-tailed Student's $t$-tests were utilized to estimate the difference between two groups, while ANOVA was used to estimate the difference among multiple groups, followed by least significant difference (LSD, with equal variance) method and Mann-Whitney $U$-test (with unequal variance). The figures were generated by Prism 6.0 (GraphPad software) (Inc., La Jolla, CA, USA). Significant differences were considered at $P<0.05(*)$. 


\section{Results}

\section{Quercetin Displays Synergetic Effect with Cisplatin but No Synergetic Effect with Paclitaxel, 5-Fluorouracil and Doxorubicin in Cervical Cancer Cells}

CCK-8 assay was utilized to determine the cytotoxic effect of individual drugs in cervical cancer cells. As shown in Figure $1 \mathrm{~A}$ and $\mathrm{B}$, quercetin suppressed the viability of $\mathrm{HeLa}$ and SiHa cells in a dose- and time-dependent manner, with an $\mathrm{IC}_{50}$ of $30 \mu \mathrm{M}$ for HeLa at $24 \mathrm{~h}$ and $50 \mu \mathrm{M}$ for $\mathrm{SiHa}$ at $48 \mathrm{~h}$. Thus, the final concentrations and time of quercetin in $\operatorname{HeLa}(0,7.5,15,30 \mu \mathrm{M}$ for $24 \mathrm{~h})$ and $\mathrm{SiHa}$ $(0,12.5,25,50 \mu \mathrm{M}$ for $48 \mathrm{~h})$ were selected in subsequent experiments. The viability of HeLa and $\mathrm{SiHa}$ cells was also dose- and time-dependently inhibited by cisplatin (Figure 1C and D), paclitaxel (Supplementary Figure 1A and 1D), 5-fluorouracil (Supplementary Figure 1B and 1E) as well as doxorubicin (Supplementary Figure 1C and $\underline{1 \mathrm{~F}}$ ).

Table I Combined Index Data on Combination Treatment of Quercetin and Cisplatin in Cervical Cancer Cells

\begin{tabular}{|c|c|c|c|}
\hline $\begin{array}{l}\text { Chemotherapeutic Drugs } \\
\text { (Concentration, } \mu \mathrm{M})\end{array}$ & Cell & $\begin{array}{l}\text { Concentration of } \\
\text { Quercetin }(\mu \mathrm{M})\end{array}$ & $\begin{array}{l}\mathrm{Cl} \\
\text { Value }\end{array}$ \\
\hline Cisplatin (10) & HeLa & $\begin{array}{l}7.5 \\
15 \\
30\end{array}$ & $\begin{array}{l}0.34 \\
0.55 \\
0.64\end{array}$ \\
\hline Cisplatin (12) & $\mathrm{SiHa}$ & $\begin{array}{l}12.5 \\
25 \\
50\end{array}$ & $\begin{array}{l}0.59 \\
0.72 \\
0.75\end{array}$ \\
\hline Paclitaxel $(0.01)$ & HeLa & $\begin{array}{l}7.5 \\
15 \\
30\end{array}$ & $\begin{array}{l}2.69 \\
1.63 \\
1.39\end{array}$ \\
\hline Paclitaxel (0.006) & $\mathrm{SiHa}$ & $\begin{array}{l}12.5 \\
25 \\
50\end{array}$ & $\begin{array}{l}1.71 \\
1.47 \\
1.61\end{array}$ \\
\hline 5-Fluorouracil (6) & HeLa & $\begin{array}{l}7.5 \\
15 \\
30\end{array}$ & $\begin{array}{l}2.60 \\
1.15 \\
1.19\end{array}$ \\
\hline 5-Fluorouracil (50) & $\mathrm{SiHa}$ & $\begin{array}{l}12.5 \\
25 \\
50\end{array}$ & $\begin{array}{l}1.15 \\
1.08 \\
1.13\end{array}$ \\
\hline Doxorubicin $(0.075)$ & HeLa & $\begin{array}{l}7.5 \\
15 \\
30\end{array}$ & $\begin{array}{l}1.48 \\
1.23 \\
1.32\end{array}$ \\
\hline Doxorubicin $(0.1)$ & $\mathrm{SiHa}$ & $\begin{array}{l}7.5 \\
15 \\
30\end{array}$ & $\begin{array}{l}1.01 \\
1.03 \\
1.22\end{array}$ \\
\hline
\end{tabular}

The inhibition rates of each drug in these two cells are summarized in Supplementary Table 1 and Supplementary Table 2 in detail. Accordingly, the $\mathrm{IC}_{30}$ values of each chemotherapeutic agent were applied in the further drugdrug interaction study (cisplatin: $10 \mu \mathrm{M}$ for HeLa, $12 \mu \mathrm{M}$ for SiHa; paclitaxel: $0.01 \mu \mathrm{M}$ for HeLa, $0.006 \mu \mathrm{M}$ for SiHa; 5-fluorouracil: $0.5 \mu \mathrm{M}$ for $\mathrm{HeLa}, 50 \mu \mathrm{M}$ for $\mathrm{SiHa}$; doxorubicin: $0.075 \mu \mathrm{M}$ for HeLa, $0.1 \mu \mathrm{M}$ for $\mathrm{SiHa}$ ).

Subsequently, quercetin supplemented with each of these four anti-cancer drugs was used to treat HeLa and $\mathrm{SiHa}$ cells. $\mathrm{CCK}-8$ results showed that the viability of HeLa and SiHa cells was further reduced by combination of quercetin and cisplatin (Figure 1E and F) or other chemotherapeutic drugs (Supplementary Figure $\underline{1 \mathrm{G}}-\underline{\mathrm{L}})$. Next, the CI values from CompuSyn software were calculated to confirm the synergetic or additive or antagonistic effects between two drugs in each group. All detailed CI values of quercetin combined with different chemotherapeutic drugs are listed in Table 1.

The CI values of quercetin in conjunction with cisplatin were $<1$, indicating that these two drugs had a synergistic effect on cervical cancer cells. However, quercetin exerted an antagonistic function on paclitaxel, 5-fluorouracil and doxorubicin in both HeLa and $\mathrm{SiHa}$ cells. Hence, the anti-tumoral role in cervical cancer of quercetin and cisplatin combination was focused on in the following studies.

\section{Quercetin Enhanced the Effect of Cisplatin on the Proliferation of Cervical Cancer Cells}

Then $15 \mu \mathrm{M}$ quercetin combined with $10 \mu \mathrm{M}$ cisplatin and $25 \mu \mathrm{M}$ quercetin combined with $12 \mu \mathrm{M}$ cisplatin were chosen as co-treatment concentrations in HeLa and $\mathrm{SiHa}$ cells for following assays, respectively. BrdU assay was used to detect the proliferation of cervical cancer cells. Compared with control group, quercetin and cisplatin inhibited the proliferation of Hela and SiHa cells, respectively (Figure 2). Furthermore, co-treatment of quercetin and cisplatin suppressed more cell proliferation in contrast to either quercetin group or cisplatin group $(P<0.05)$.

\section{Quercetin Heightened the Effects of Cisplatin on the Migration and Invasion of Cervical Cancer Cells}

Transwell chambers without matrigel were utilized to evaluate the combined effect of quercetin and cisplatin 
A
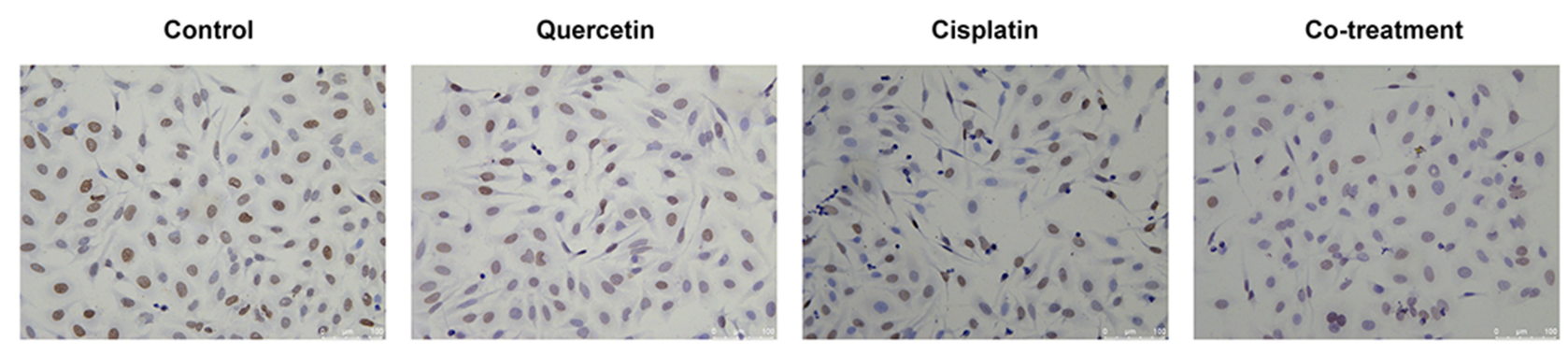

B
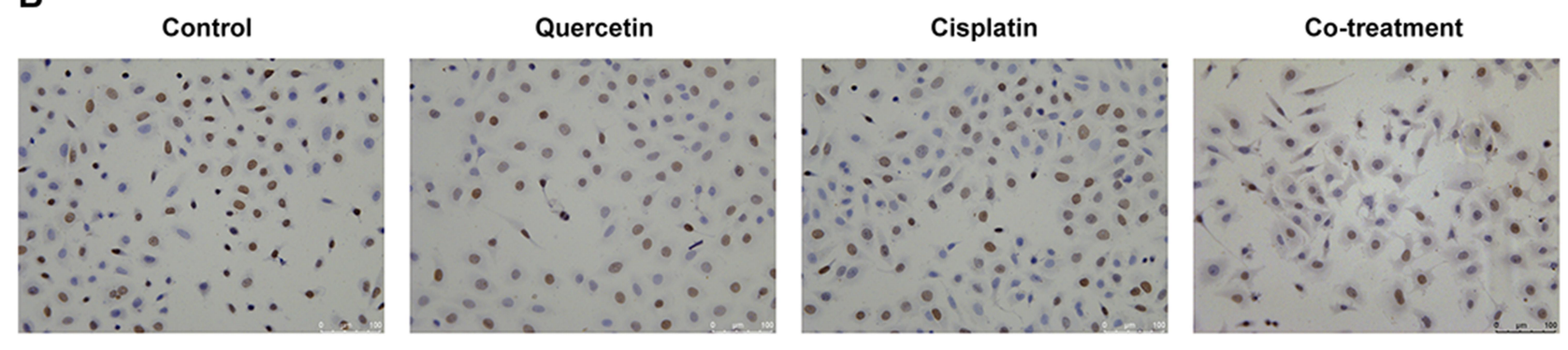

C

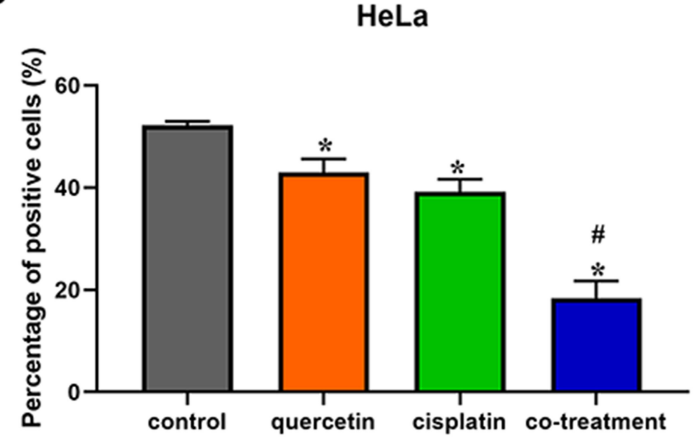

D

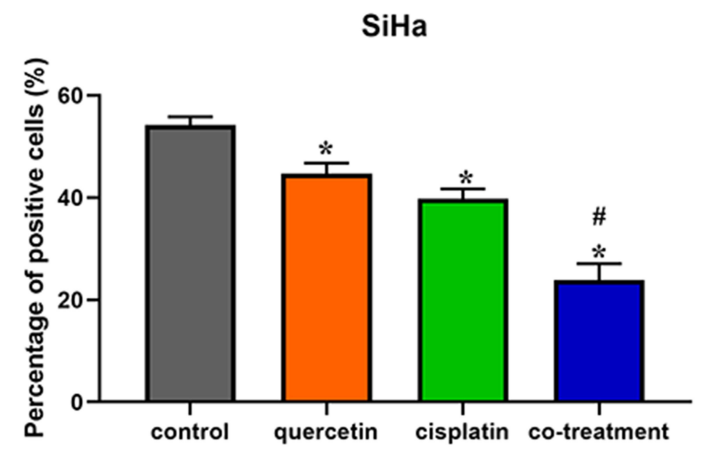

Figure 2 The effects of quercetin combined with cisplatin on the cell proliferation in cervical cancer cells. HeLa (A) and SiHa (B) cells were treated with control (complete culture medium), quercetin ( $15 \mu \mathrm{M}$ for HeLa and $30 \mu \mathrm{M}$ for $\mathrm{SiHa}$ ), cisplatin ( $10 \mu \mathrm{M}$ for HeLa and I $2 \mu \mathrm{M}$ for SiHa) or the co-treatment of quercetin and cisplatin. The ratios of cell proliferation were assessed by $\mathrm{BrdU}$ assay. The bars represent the ratios of cell proliferation in each group. Data of $\mathrm{HeLa}(\mathbf{C})$ and $\mathrm{SiHa}(\mathbf{D})$ are expressed as means $\pm \mathrm{SD}$ deviation of three independent experiments. ${ }^{*} P<0.05$ vs control group, ${ }^{\#} P<0.05$ vs cisplatin group.

Abbreviation: BrdU, bromodeoxyuridine.

on the migration of HeLa and $\mathrm{SiHa}$ cells. Compared with control group, cisplatin and quercetin inhibited the migration of cervical cancer cells, respectively, while co-treatment with the two drugs had the strongest inhibitory effect (Figure 3, $P<0.05$ ). To further detect the co-effect of the two drugs on the invasion of cervical cancer cells, $5 \times 10^{4} \mathrm{HeLa}$ or SiHa cells treated with drugs were placed into transwell chambers with matrigel for $24 \mathrm{~h}$. The results, depicted in Figure 4, suggested that quercetin synergized with cisplatin to reduce the invading cervical cancer cells.

\section{Quercetin Promoted the Effect of Cisplatin on the Apoptosis of Cervical Cancer Cells}

Flow cytometry based on Annexin-V/PI double staining analysis was performed to investigate the influence of quercetin on cisplatin-induced apoptosis of cervical cancer cells. In contrast to control group, quercetin enhanced the percentage of cell apoptosis as shown in Figure 4. Besides, combination of quercetin and cisplatin could accelerate apoptosis both of $\mathrm{HeLa}$ and SiHa cells compared with cisplatin group (Figure 5, 
A
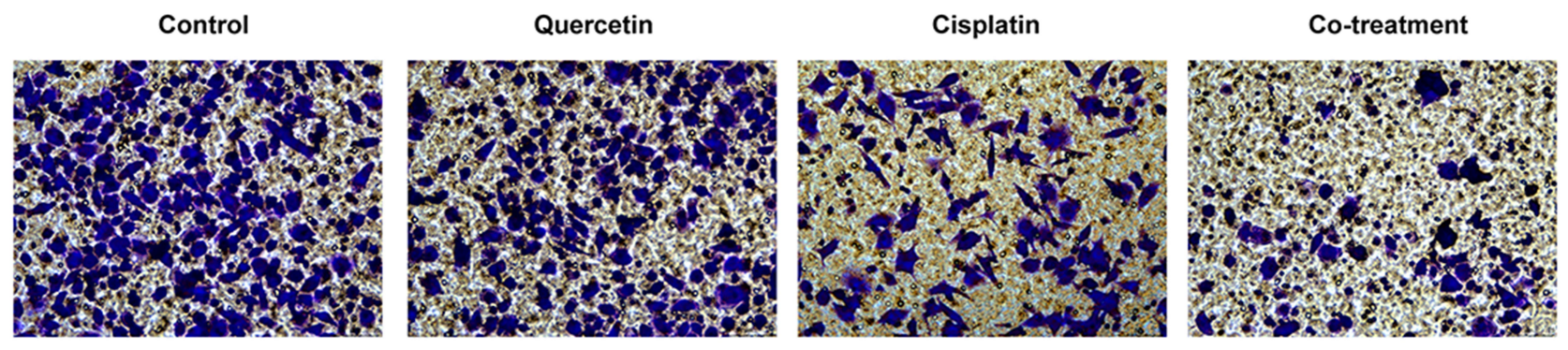

B
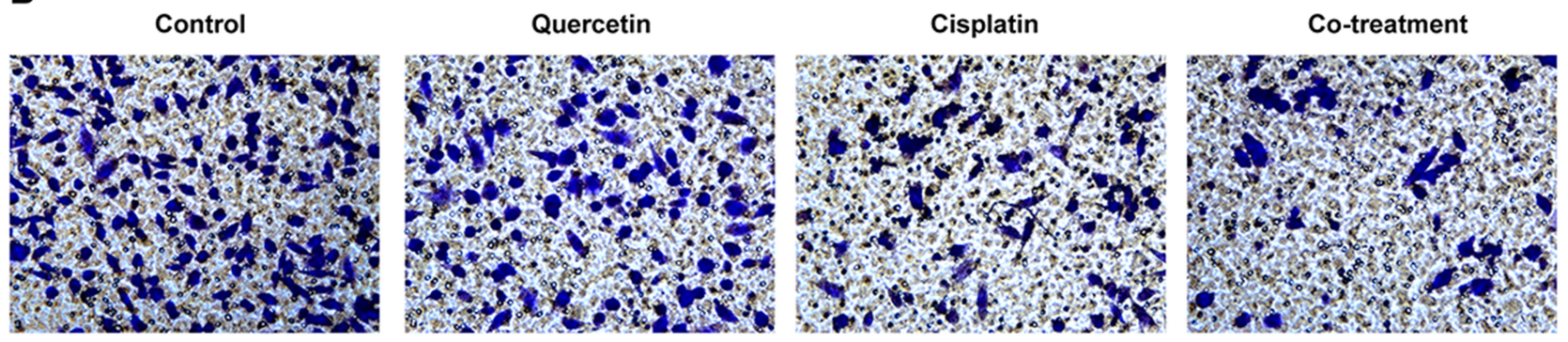

C

HeLa

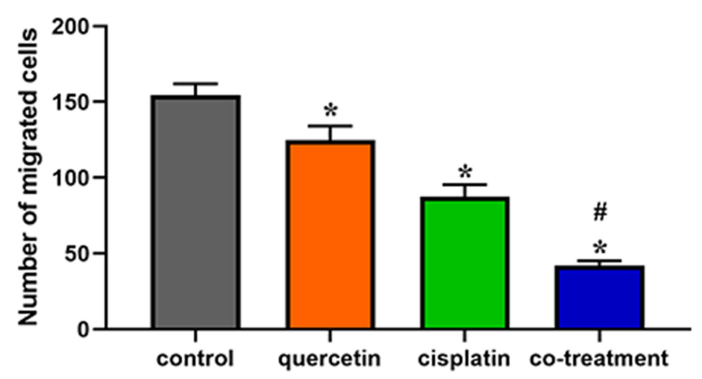

$\mathrm{SiHa}$

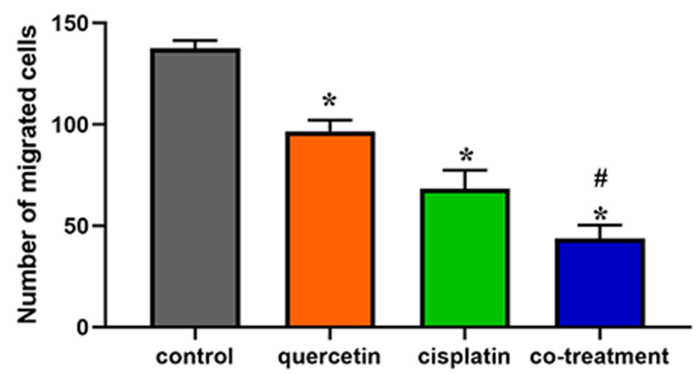

Figure 3 Quercetin enhanced the effect of cisplatin on the migration of cervical cancer cells. HeLa (A) and SiHa (B) cells were treated with control (complete culture medium), quercetin ( $15 \mu \mathrm{M}$ for HeLa and $30 \mu \mathrm{M}$ for SiHa), cisplatin ( $10 \mu \mathrm{M}$ for HeLa and $12 \mu \mathrm{M}$ for SiHa) or the co-treatment of quercetin and cisplatin. The bars represent the ratios of the migrated cell numbers in each group. Data of $\mathrm{HeLa}(\mathbf{C})$ and $\mathrm{SiHa}(\mathbf{D})$ are expressed as means $\pm \mathrm{SD}$ deviation of three independent experiments. $* P<0.05$ vs control group, ${ }^{\#} P<0.05$ vs cisplatin group.

$P<0.05)$. The results indicated that quercetin increased cisplatin-mediated apoptosis of cervical cancer cells.

\section{Quercetin Increased the Effect of Cisplatin on the Expression of MMP2, Ezrin, P-Gp and METTL3 Protein in Cervical Cancer Cells}

To further clarify the role of quercetin on cisplatin chemosensitivity, Western blotting was used to detect the expression level of MMP2, ezrin, METTL3 and drug-resistance protein P-Gp in HeLa and SiHa cells. As shown in Figure 6, cisplatin had no significant effect on the expression of MMP2, while cisplatin decreased the expression of ezrin markedly $(P<0.05)$. There was no statistical difference in the expression levels of MMP2 and ezrin between quercetin group and control group. The expressions of MMP2 and ezrin in co-treatment group were clearly lower than those in cisplatin group $(P<$ $0.05)$. Both of cisplatin and quercetin suppressed the expression levels of P-Gp and METTL3, and the combination of quercetin and cisplatin further repressed those proteins' expression levels $(P<0.05)$. The result might indicate that quercetin activated cytotoxicity of cisplatin through downregulating the expression of ezrin, MMP2, P-Gp and METTL3 protein.

\section{Discussion}

With the emergence of monotherapy resistance in cervical cancer cells, the combined application of multiple drugs is becoming a trend. ${ }^{20}$ Various substances extracted from plants, including quercetin and curcumin, can inhibit the 
A
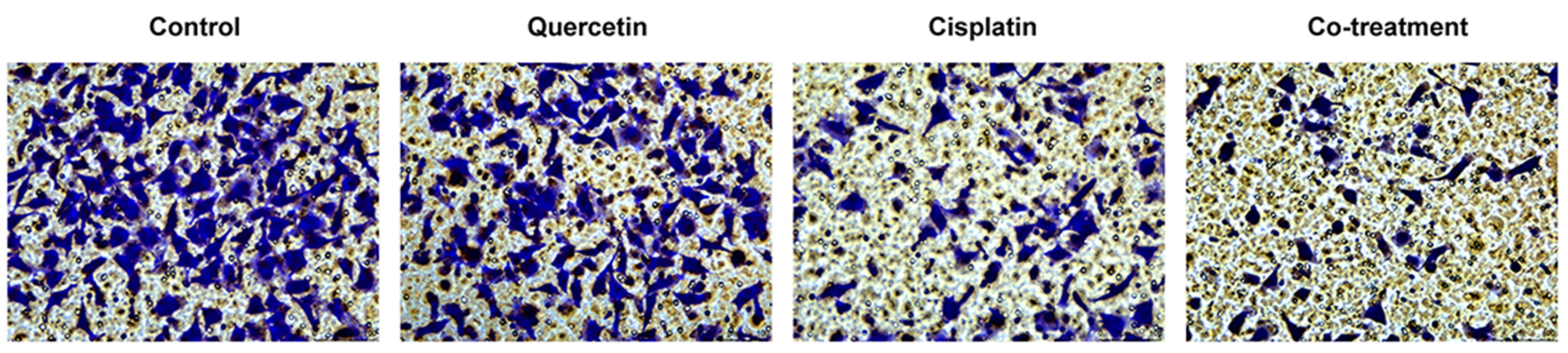

\section{B}
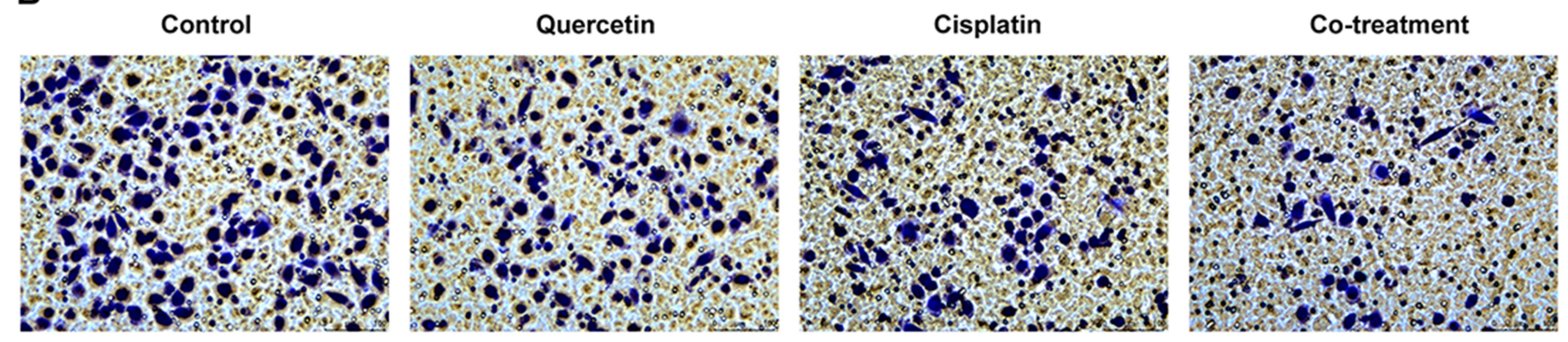

C

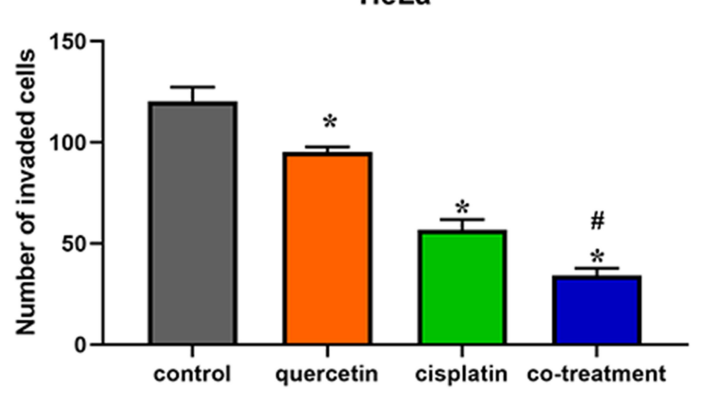

D

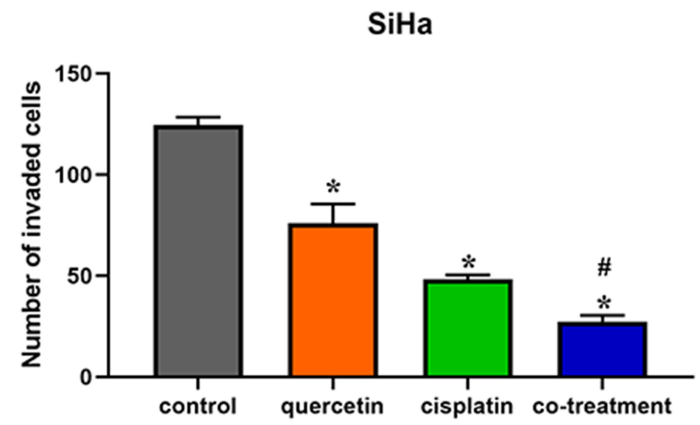

Figure 4 Quercetin promoted the effect of cisplatin on the invasion of cervical cancer cells. HeLa (A) and SiHa (B) cells were treated with control (complete culture medium), quercetin (I5 $\mu \mathrm{M}$ for HeLa and $30 \mu \mathrm{M}$ for SiHa), cisplatin (10 $\mu \mathrm{M}$ for HeLa and I $2 \mu \mathrm{M}$ for SiHa) or the co-treatment of quercetin and cisplatin. The bars represent the ratios of the invaded cell numbers in each group. Data of HeLa $(\mathbf{C})$ and $\mathrm{SiHa}(\mathbf{D})$ are expressed as means \pm SD deviation of three independent experiments. $* P<0.05$ vs control group, ${ }^{\#} P<0.05$ vs cisplatin group.

malignant biological behavior of cancer cells. ${ }^{21-23}$ Quercetin, a versatile antioxidant, decreases the hazard of cardiovascular diseases, metabolic disorders and various cancers. $^{22,24}$ Pozsgai et $\mathrm{al}^{25}$ showed that quercetin enhanced selectively the sensitivity of cancer cells to radiotherapy and chemotherapy, but spared normal cells. To date, there have been various studies focusing on combined effect of quercetin and several chemotherapeutic drugs on cancer cells. ${ }^{26-30}$ Cisplatin is one of the most common and extensively used chemicals for multiple solid tumors including cervical cancer. ${ }^{31}$ Paclitaxel, 5-fluorouracil and doxorubicin have been utilized in treatment of many solid tumors, and increasing evidence illustrates that quercetin could enhance the efficacy of these chemotherapeutic drugs, ${ }^{32}$ although $5 \mu \mathrm{M}-30 \mu \mathrm{M}$ quercetin weakened pro-apoptotic effects of cisplatin, paclitaxel and 5-fluorouracil in ovarian cancer cells. ${ }^{26}$ However, so far, the combination effect of quercetin with cisplatin, paclitaxel, 5-fluorouracil and doxorubicin on cervical cancer cells has not been reported. In our study, quercetin synergized with cisplatin to inhibit the growth of HeLa and SiHa cells, while quercetin could not enhance the inhibitory effect of paclitaxel, 5-fluorouracil and doxorubicin on the proliferation of cervical cancer cells. This means that these three chemotherapeutic drugs might not be suitable for combination with quercetin in cervical cancer cells. Since tolerance to cisplatin might lead to recurrence or disease progression of cervical cancer, ${ }^{7,33}$ the addition of quercetin has the possibility to overcome cisplatin resistance. 
A

Control

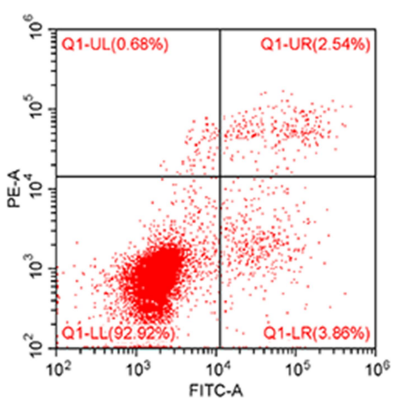

B

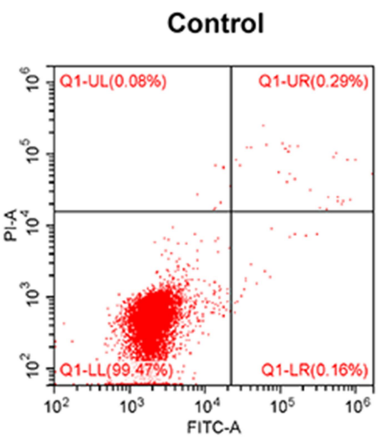

C

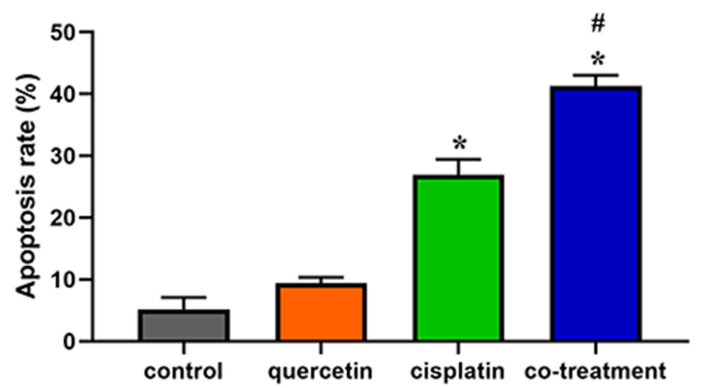

Quercetin

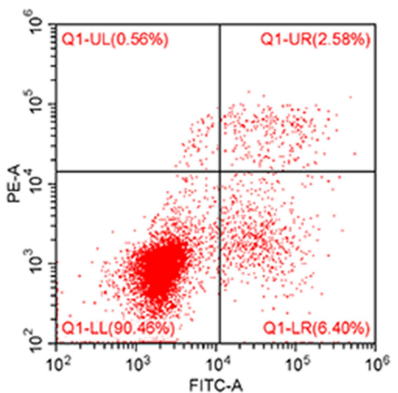

Quercetin

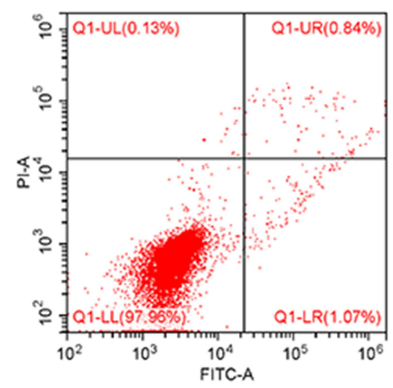

HeLa
Cisplatin

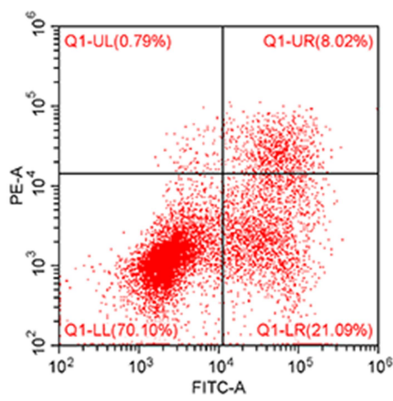

Cisplatin

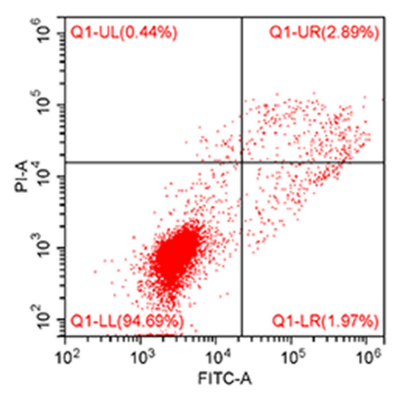

D

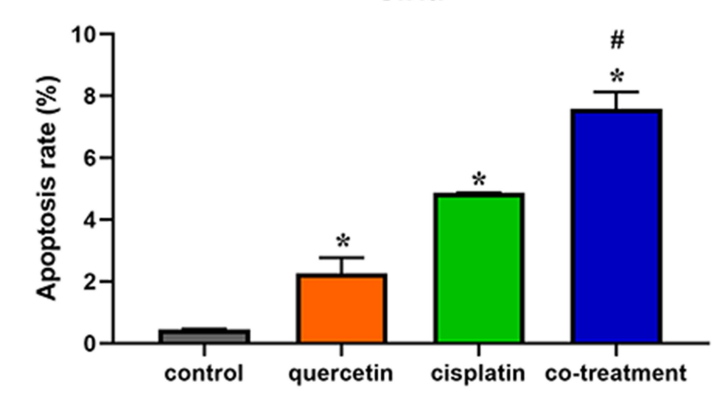

Co-treatment

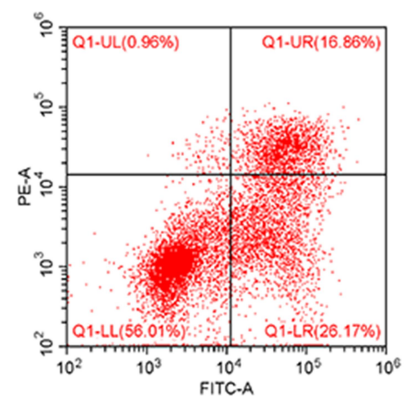

Co-treatment

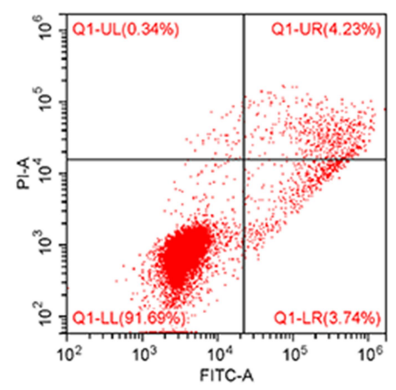

$\mathrm{SiHa}$

Figure 5 Quercetin elevated the effect of cisplatin on the apoptosis of cervical cancer cells. HeLa (A) and $\mathrm{SiHa}(\mathbf{B})$ cells were treated with control (complete culture medium), quercetin ( $15 \mu \mathrm{M}$ for HeLa and $30 \mu \mathrm{M}$ for $\mathrm{SiHa}$ ), cisplatin ( $10 \mu \mathrm{M}$ for HeLa and $12 \mu \mathrm{M}$ for SiHa) or the co-treatment of quercetin and cisplatin. The bars represent the ratios of the apoptotic cells in each group. Data of HeLa $(\mathbf{C})$ and $\mathrm{SiHa}(\mathbf{D})$ are expressed as means $\pm \mathrm{SD}$ deviation of three independent experiments. $* P<0.05$ vs control group, ${ }^{\#} P<0.05$ vs cisplatin group.

Metastasis is one of the most important characteristics of malignant tumors and often results in treatment failure and poor prognosis. ${ }^{34}$ Mounting evidence has confirmed that ezrin and MMP2 are critical molecules involved in migration and invasion of tumors including cervical cancer. ${ }^{35,36}$ In our study, quercetin enhanced the inhibitory effect of cisplatin on the migration and invasion of cervical cancer cells. Further research found that although quercetin only inhibited slightly the expression of ezrin in HeLa and had no effect on that in SiHa, the combination of quercetin and cisplatin could enhance the effect of cisplatin on the expression of ezrin protein in $\mathrm{HeLa}$ and $\mathrm{SiHa}$ cells. Surprisingly, the treatment with cisplatin or quercetin alone did not reduce the expression of MMP2 protein, but co-treatment caused marked suppression, which suggests that a low dose of cisplatin or quercetin has no effect on the MMP2 protein level, while cotreatment might amplify the cytotoxic effect and inhibit the migration and invasion of cervical cancer cells via downregulating the MMP2 expression.

Multidrug resistance (MDR) is a phenomenon that cancer cells show cross-resistance to many chemotherapeutic drugs and results in chemotherapy failure. P-glycoprotein (P-Gp), one of the transporters involved in MDR, is often overexpressed in drug-resistant cancer cells. ${ }^{37}$ Increasing research has demonstrated that downregulation of P-Gp expression 

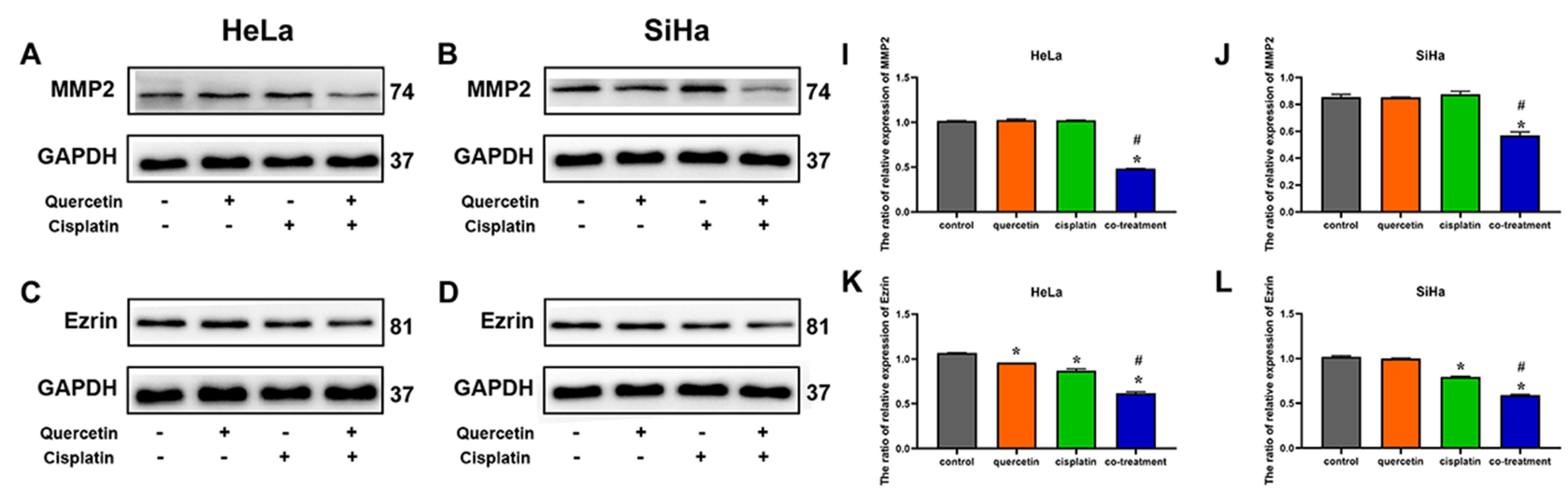

L
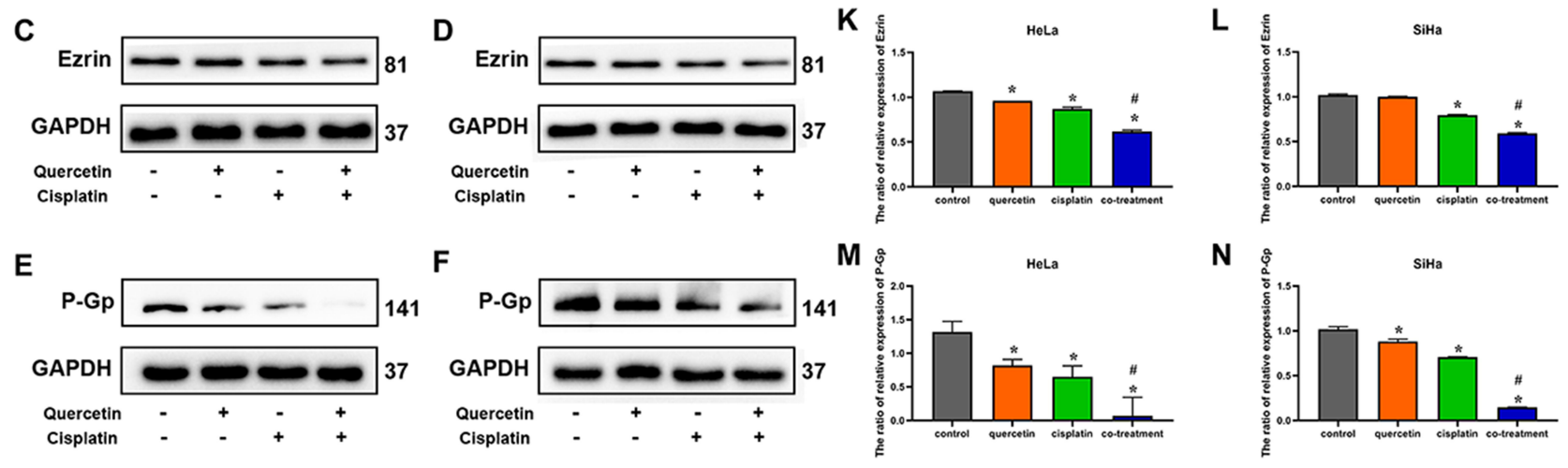

N
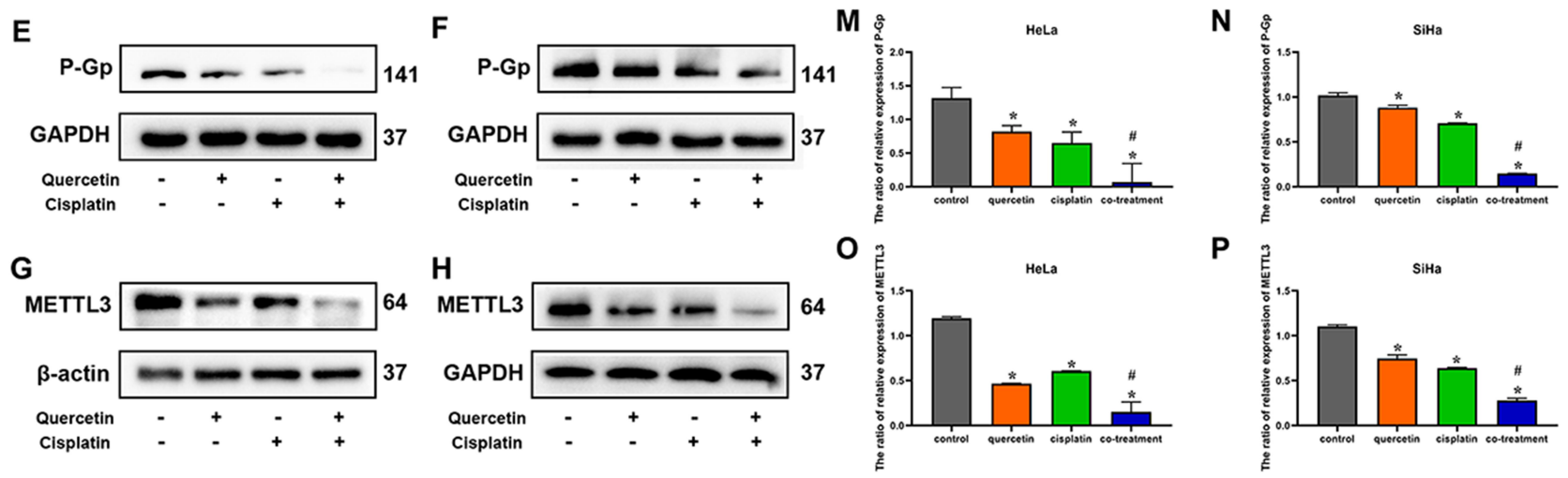

Figure 6 The effects of quercetin combined with cisplatin on the P-Gp and METTL3 protein expression in cervical cancer cells. Western blot was used for the detection of MMP2 after drug treatment in HeLa (A) and SiHa cells (B), the detection of ezrin in HeLa (C) and SiHa (D), the detection of P-Gp in HeLa (E) and SiHa cells (F) and the detection of METTL3 in HeLa (G) and SiHa cells $\mathbf{( H )}$. The bar graphs represent the ratios of MMP2, ezrin, P-Gp and METTL3 relative expressions compared with internal parameter in HeLa and $\mathrm{SiHa}$ cells $(\mathbf{I}-\mathbf{P})$. Data are expressed as means $\pm \mathrm{SD}$ deviation of three independent experiments. ${ }^{* P}<0.05$ vs control group, ${ }^{\#} P<0.05$ vs cisplatin group.

contributed to elevate chemosensitivity of cancer cells. ${ }^{20,38}$ Zhang et $\mathrm{al}^{39}$ showed that 7-O-geranylquercetin, a derivative of quercetin, reversed doxorubicin resistance through reducing P-Gp expression. In our study, quercetin could enhance the apoptosis-promoting effect of cisplatin in cervical cancer cells via decreasing P-Gp expression. However, many potential signaling ways in ameliorating chemoresistance are still poorly understood and need further investigation.

METTL3 was demonstrated to be involved in the occurrence and development of multiple cancers and exerted distinct functions in different types of cancers. ${ }^{40}$ In most cases, METTL3 acted as an oncogene to promote the growth of cancer cells such as breast cancer and ovarian cancer. ${ }^{41,42}$ However, in renal cancer and colorectal cancer, METTL3 acted as a tumor suppressor. ${ }^{43,44}$ It has been reported that METTL 3 could enhance cisplatin resistance in seminoma, ${ }^{45}$ and knockdown of METTL3 weakened cisplatin resistance in pancreatic cancer. ${ }^{46}$ For cervical cancer cells, it was noticed that downregulation of METTL3 suppressed malignant biologic behavior of cancer cells in vitro. ${ }^{47}$ However, the relationship between METTL3 expression and cisplatin sensitivity in cervical cancer is poorly understood. In our study, it was demonstrated that quercetin potentiated HeLa and SiHa cells chemosensitivity to cisplatin by repressing METTL3 protein expression.

To summarize, this study found that quercetin promoted cisplatin cytotoxicity through promoting apoptosis and inhibiting proliferation, migration and invasion of cervical cancer cells, which offers an experimental proof for treating cisplatin-resistant patients. In addition, we further searched for the mechanism of quercetin effect on cisplatin efficacy and showed that quercetin downregulated the MMP2, ezrin, P-Gp and METTL3 expression to enhance chemosensitivity in cervical cancer cells. However, the combined effect of quercetin and cisplatin should be verified in in vivo experiments. Furthermore, various signaling ways involved in cotreatment should be investigated by multiple studies. In addition, quercetin enhanced the adverse effects in the predamaged kidney based on animal trials, ${ }^{48}$ which indicated that quercetin might put cervical cancer patients with 
kidney dysfunction at risk. At present, the reported incidence of harmful effect of quercetin on humans is very low, but this cannot be seen as evidence that no adverse effects were observed. More studies focused on the adverse reactions of quercetin need to be done.

\section{Abbreviation}

$\mathrm{BCA}$, bicinchoninic acid; BrdU, bromodeoxyuridine; CCK-8, Cell Counting Kit-8; CI, combination index; DAB, diaminobenzidine; DMEM, Dulbecco's modified Eagle's Medium; DMSO, dimethyl sulfoxide; HCL, hydrochloric acid; LSD, least significant difference; MDR, multidrug resistance; METTL3, methyltransferase-like 3; MMP2, matrix metallopeptidase 2; PBS, Phosphate Buffered Saline; P-Gp, P-glycoprotein; PI, propidium iodide; PVDF, polyvinylidene difluoride; RIPA, radio immunoprecipitation assay; SD, standard deviation; TBST, tris buffered saline Tween.

\section{Funding}

The study was supported by funds from Natural Science Foundation of China (No. 81974282) and grants from Science and Technology Planning Project of Wenzhou City (No. Y2020187).

\section{Disclosure}

The authors report no conflicts of interest in this work.

\section{References}

1. Siegel RL, Miller KD, Jemal A. Cancer statistics, 2020. CA Cancer J Clin. 2020;70(1):7-30. doi:10.3322/caac.21590

2. Tsikouras P, Zervoudis S, Manav B, et al. Cervical cancer: screening, diagnosis and staging. $J$ BUON. 2016;21(2):320-325.

3. Cohen PA, Jhingran A, Oaknin A, Denny L. Cervical cancer. Lancet. 2019;393(10167):169-182. doi:10.1016/S0140-6736(18)32470-X

4. Zhu H, Chen A, Li S, et al. Predictive role of galectin-1 and integrin alpha5beta1 in cisplatin-based neoadjuvant chemotherapy of bulky squamous cervical cancer. Biosci Rep. 2017;37:5.

5. Duenas-Gonzalez A, Gonzalez-Fierro A. Pharmacodynamics of current and emerging treatments for cervical cancer. Expert Opin Drug Metab Toxicol. 2019;15(8):671-682. doi:10.1080/17425255.20 19.1648431

6. Kumar L, Harish P, Malik PS, Khurana S. Chemotherapy and targeted therapy in the management of cervical cancer. Curr Probl Cancer 2018;42(2):120-128. doi:10.1016/j.currproblcancer.2018.01.016

7. Zhu H, Luo H, Zhang W, Shen Z, Hu X, Zhu X. Molecular mechanisms of cisplatin resistance in cervical cancer. Drug Des Devel Ther. 2016;10:1885-1895. doi:10.2147/DDDT.S106412

8. Li J, Chen Q, Deng Z, et al. KRT17 confers paclitaxel-induced resistance and migration to cervical cancer cells. Life Sci. 2019;224:255-262. doi:10.1016/j.1fs.2019.03.065

9. Mutlu P, Yalcin Azarkan S, Taghavi Pourianazar N, Yucel M, Gunduz U. Determination of the relationship between doxorubicin resistance and Wnt signaling pathway in HeLa and K562 cell lines. EXCLI J. 2018;17:386-398. doi:10.17179/excli2018-1129
10. Yan CM, Zhao YL, Cai HY, Miao GY, Ma W. Blockage of PTPRJ promotes cell growth and resistance to 5-FU through activation of JAK1/STAT3 in the cervical carcinoma cell line C33A. Oncol Rep. 2015;33(4):1737-1744. doi:10.3892/or.2015.3769

11. Regalado Porras GO, Chavez Nogueda J, Poitevin Chacon A. Chemotherapy and molecular therapy in cervical cancer. Rep Pract Oncol Radiother. 2018;23(6):533-539. doi:10.1016/j.rpor.2018.09.002

12. Lin R, Piao M, Song Y, Liu C. Quercetin suppresses AOM/ DSS-induced colon carcinogenesis through its anti-inflammation effects in mice. J Immunol Res. 2020;2020:9242601. doi:10.1155/ 2020/9242601

13. Prieto-Vila M, Shimomura I, Kogure A, et al. Quercetin inhibits lef1 and resensitizes docetaxel-resistant breast cancer cells. Molecules. 2020;25:11. doi:10.3390/molecules25112576

14. Clemente-Soto AF, Salas-Vidal E, Milan-Pacheco C, SanchezCarranza JN, Peralta-Zaragoza O, Gonzalez-Maya L. Quercetin induces G2 phase arrest and apoptosis with the activation of p53 in an E6 expression-independent manner in HPV-positive human cervical cancer-derived cells. Mol Med Rep. 2019;19(3):2097-2106. doi: $10.3892 / \mathrm{mmr} .2019 .9850$

15. Kedhari Sundaram M, Hussain A, Haque S, Raina R, Afroze N. Quercetin modifies $5^{\prime} \mathrm{CpG}$ promoter methylation and reactivates various tumor suppressor genes by modulating epigenetic marks in human cervical cancer cells. $J$ Cell Biochem. 2019;120 (10):18357-18369. doi:10.1002/jcb.29147

16. Kedhari Sundaram M, Raina R, Afroze N, et al. Quercetin modulates signaling pathways and induces apoptosis in cervical cancer cells. Biosci Rep. 2019;39:8. doi:10.1042/BSR20190720

17. Zhang $\mathrm{X}$, Huang J, Yu C, et al. Quercetin enhanced paclitaxel therapeutic effects towards PC-3 prostate cancer through ER stress induction and ROS production. Onco Targets Ther. 2020;13:513-523. doi:10.2147/OTT.S228453

18. Li X, Guo S, Xiong XK, et al. Combination of quercetin and cisplatin enhances apoptosis in OSCC cells by downregulating xIAP through the NF-kappaB pathway. $J$ Cancer. 2019;10(19):4509-4521. doi: $10.7150 /$ jca. 31045

19. Chou TC. Theoretical basis, experimental design, and computerized simulation of synergism and antagonism in drug combination studies. Pharmacol Rev. 2006;58(3):621-681. doi:10.1124/pr.58.3.10

20. Abdallah HM, Al-Abd AM, El-Dine RS, El-Halawany AM. P-glycoprotein inhibitors of natural origin as potential tumor chemo-sensitizers: A review. $J$ Adv Res. 2015;6(1):45-62. doi:10.1016/j.jare.2014.11.008

21. Ghasemi F, Shafiee M, Banikazemi Z, et al. Curcumin inhibits NF-kB and Wnt/beta-catenin pathways in cervical cancer cells. Pathol Res Pract. 2019;215(10):152556. doi:10.1016/j.prp.2019.152556

22. Anand David AV, Arulmoli R, Parasuraman S. Overviews of biological importance of quercetin: a bioactive flavonoid. Pharmacogn Rev. 2016;10(20):84-89. doi:10.4103/0973-7847.194044

23. Pourhanifeh MH, Darvish M, Tabatabaeian J, et al. Therapeutic role of curcumin and its novel formulations in gynecological cancers. J Ovarian Res. 2020;13(1):130. doi:10.1186/s13048-020-00731-7

24. Vafadar A, Shabaninejad Z, Movahedpour A, et al. Quercetin and cancer: new insights into its therapeutic effects on ovarian cancer cells. Cell Biosci. 2020;10:32. doi:10.1186/s13578-020-00397-0

25. Pozsgai E, Bellyei S, Cseh A, et al. Quercetin increases the efficacy of glioblastoma treatment compared to standard chemoradiotherapy by the suppression of PI-3-kinase-Akt pathway. Nutr Cancer. 2013;65(7):1059-1066. doi:10.1080/01635581.2013.810291

26. Li N, Sun C, Zhou B, et al. Low concentration of quercetin antagonizes the cytotoxic effects of anti-neoplastic drugs in ovarian cancer. PLoS One. 2014;9(7):e100314.

27. Chuang-Xin L, Wen-Yu W, Yao C, Xiao-Yan L, Yun Z. Quercetin enhances the effects of 5-fluorouracil-mediated growth inhibition and apoptosis of esophageal cancer cells by inhibiting NF-kappaB. Oncol Lett. 2012;4(4):775-778. doi:10.3892/ol.2012.829 
28. Dai W, Gao Q, Qiu J, Yuan J, Wu G, Shen G. Quercetin induces apoptosis and enhances 5-FU therapeutic efficacy in hepatocellular carcinoma. Tumour Biol. 2016;37(5):6307-6313. doi:10.1007/ s13277-015-4501-0

29. Li S, Yuan S, Zhao Q, Wang B, Wang X, Li K. Quercetin enhances chemotherapeutic effect of doxorubicin against human breast cancer cells while reducing toxic side effects of it. Biomed Pharmacother. 2018;100:441-447. doi:10.1016/j.biopha.2018.02.055

30. Liu H, Lee JI, Ahn TG. Effect of quercetin on the anti-tumor activity of cisplatin in EMT6 breast tumor-bearing mice. Obstet Gynecol Sci. 2019;62(4):242-248.

31. Ghosh S. Cisplatin: the first metal based anticancer drug. Bioorg Chem. 2019;88:102925. doi:10.1016/j.bioorg.2019.102925

32. Maciejczyk A, Surowiak P. Quercetin inhibits proliferation and increases sensitivity of ovarian cancer cells to cisplatin and paclitaxel. Ginekol Pol. 2013;84(7):590-595. doi:10.17772/gp/1609

33. Eskander RN, Tewari KS. Chemotherapy in the treatment of metastatic, persistent, and recurrent cervical cancer. Curr Opin Obstet Gynecol. 2014;26(4):314-321. doi:10.1097/GCO.0000000000000042

34. Bakir B, Chiarella AM, Pitarresi JR, Rustgi AK. EMT, MET, Plasticity, and Tumor Metastasis. Trends Cell Biol. 2020;30 (10):764-776. doi:10.1016/j.tcb.2020.07.003

35. Xi M, Tang W. Knockdown of Ezrin inhibited migration and invasion of cervical cancer cells in vitro. Int J Immunopathol Pharmacol. 2020;34:2058738420930899. doi:10.1177/2058738420930899

36. Kessenbrock K, Plaks V, Werb Z. Matrix metalloproteinases: regulators of the tumor microenvironment. Cell. 2010;141(1):52-67. doi:10.1016/j.cell.2010.03.015

37. Xue C, Wang C, Liu Q, et al. Targeting P-glycoprotein expression and cancer cell energy metabolism: combination of metformin and 2-deoxyglucose reverses the multidrug resistance of K562/Dox cells to doxorubicin. Tumour Biol. 2016;37(7):8587-8597. doi:10.1007/ s13277-015-4478-8

38. Sachs J, Kadioglu O, Weber A, et al. Selective inhibition of P-gp transporter by goniothalamin derivatives sensitizes resistant cancer cells to chemotherapy. J Nat Med. 2019;73(1):226-235. doi:10.1007/ s11418-018-1230-x
39. Zhang E, Liu J, Shi L, et al. 7-O-geranylquercetin contributes to reverse P-gp-mediated adriamycin resistance in breast cancer. Life Sci. 2019;238:116938. doi:10.1016/j.lfs.2019.116938

40. Zeng C, Huang W, Li Y, Weng H. Roles of METTL3 in cancer: mechanisms and therapeutic targeting. J Hematol Oncol. 2020;13 (1):117. doi:10.1186/s13045-020-00951-w

41. Wang H, Xu B, Shi J. N6-methyladenosine METTL3 promotes the breast cancer progression via targeting Bcl-2. Gene. 2020;722:144076.

42. Liang S, Guan H, Lin X, Li N, Geng F, Li J. METTL3 serves an oncogenic role in human ovarian cancer cells partially via the AKT signaling pathway. Oncol Lett. 2020;19(4):3197-3204. doi:10.3892/ ol.2020.11425

43. Li X, Tang J, Huang W, et al. The M6A methyltransferase METTL3: acting as a tumor suppressor in renal cell carcinoma. Oncotarget. 2017;8(56):96103-96116. doi:10.18632/oncotarget.21726

44. Deng R, Cheng Y, Ye S, et al. m(6) A methyltransferase METTL3 suppresses colorectal cancer proliferation and migration through $\mathrm{p} 38$ / ERK pathways. Onco Targets Ther. 2019;12:4391-4402. doi:10.2147/OTT.S201052

45. Wei J, Yin Y, Zhou J, et al. METTL3 potentiates resistance to cisplatin through $\mathrm{m}(6)$ A modification of TFAP2C in seminoma. J Cell Mol Med. 2020;24(19):11366-11380. doi:10.1111/jcmm.15738

46. Taketo K, Konno M, Asai A, et al. The epitranscriptome m6A writer METTL3 promotes chemo- and radioresistance in pancreatic cancer cells. Int J Oncol. 2018;52(2):621-629. doi:10.3892/ijo.2017.4219

47. Hu Y, Li Y, Huang Y, et al. METTL3 regulates the malignancy of cervical cancer via post-transcriptional regulation of RAB2B. Eur J Pharmacol. 2020;879:173134. doi:10.1016/j.ejphar.2020.173134

48. Andres S, Pevny S, Ziegenhagen R, et al. Safety aspects of the use of quercetin as a dietary supplement. Mol Nutr Food Res. 2018;62:1. doi:10.1002/mnfr.201700447

\section{Publish your work in this journal}

Drug Design, Development and Therapy is an international, peerreviewed open-access journal that spans the spectrum of drug design and development through to clinical applications. Clinical outcomes, patient safety, and programs for the development and effective, safe, and sustained use of medicines are a feature of the journal, which has also been accepted for indexing on PubMed Central. The manuscript management system is completely online and includes a very quick and fair peer-review system, which is all easy to use. Visit http://www. dovepress.com/testimonials.php to read real quotes from published authors. 